\title{
The effects of intraruminal infusions of sodium bicarbonate, ammonium chloride and sodium butyrate on urea metabolism in sheep
}

\author{
By B. W. NORTON,* A. N. JANES AND D. G. ARMSTRONG \\ Department of Agricultural Biochemistry and Nutrition, School of Agriculture, \\ The University of Newcasile upon Tyne, $7 R U$ NEI
}

\section{(Received 28 May 1981 - Accepted 12 December 1981)}

\begin{abstract}
1. Three sheep fitted with rumen cannulas were fed hourly a daily ration of $1000 \mathrm{~g}$ pelleted-grass cubes, and during four successive 2 -week periods were intraruminally infused $(0.451 / \mathrm{d})$ with solutions containing sodium chloride $(0.47 \mathrm{~mol} / \mathrm{d})$, sodium bicarbonate $(0.47 \mathrm{~mol} / \mathrm{d})$, ammonium chloride $(0.47 \mathrm{~mol} / \mathrm{d})$ and sodium butyrate $(0.47 \mathrm{~mol} / \mathrm{d})$. Each solution, except that for $\mathrm{NaHCO}_{3}$, was adjusted to $\mathrm{pH} 7$ before infusion, and provided equal sodium intakes for sheep in all periods.

2. In the final week of each infusion period, a balance trial was conducted and on separate days each sheep was continuously infused with $\left[{ }^{14} \mathrm{C}\right]$ urea and $\mathrm{NaH}^{14} \mathrm{CO}_{3}$ intravenously and $\mathrm{NaH}^{14} \mathrm{CO}_{3}$ intraruminally. Carbon transfer rates between blood urea, blood bicarbonate and rumen fluid bicarbonate were calculated from the specific radioactivity of urea and bicarbonate samples and isotope infusion rates during each experimental period.

3. There was no significant effect of intraruminal infusions on $\mathrm{N}$ balance, and with the exception of sheep infused with $\mathrm{NH}_{4} \mathrm{Cl}$, all sheep utilized apparently digested $\mathrm{N}$ with similar efficiency for $\mathrm{N}$ retention. Sheep infused with $\mathrm{NH}_{4} \mathrm{Cl}(6 \cdot 2 \mathrm{~g} \mathrm{~N} / \mathrm{d})$ excreted the equivalent of $93 \%$ of the infused $\mathrm{N}$ as urea in urine.

4. Infusion of $\mathrm{NaHCO}_{3}, \mathrm{NH}_{4} \mathrm{Cl}$ and sodium butyrate significantly $(P<0.05)$ increased the rumen fluid concentrations of bicarbonate, ammonia and butyric acid respectively, and all infusions significantly $(P<0.05)$ increased total volatile fatty acid concentrations. Both $\mathrm{NaHCO}_{3}$ and sodium butyrate significantly $(P<0.05)$ increased the $\mathrm{pH}$ of rumen fluid. There was no significant effect of infusion on the proportions of propionic acid or the osmolality of rumen fluid.

5. Intraruminal infusions of $\mathrm{NH}_{4} \mathrm{Cl}$ significantly $(P<0.05)$ increased and infusion of sodium butyrate significantly $(P<0.05)$ decreased plasma urea concentrations. Sheep infused with $\mathrm{NH}_{4} \mathrm{Cl}$ had higher rates of urea synthesis and urinary urea excretion compared with sheep on the other treatments, and a significantly $(P<0.05)$ lower proportion of urea synthesized by these sheep was degraded in the digestive tract. Sheep infused with sodium butyrate degraded a significantly $(P<0.05)$ greater amount $(3.2 \mathrm{~g} \mathrm{~N} / \mathrm{d})$ and proportion $(0.24)$ of total urea synthesis in the rumen than did shcep infused with $\mathrm{NaCl}$. Corresponding values for the control ( $\mathrm{NaCl}$ ) sheep were $1.5 \mathrm{~g} \mathrm{~N} / \mathrm{d}$ and 0.13 respectively. There was no significant effect of other infusions on the amount of urea recycled to the rumen or on the distribution of total urea degradation between the rumen and lower digestive tract. Plasma urea clearance to the rumen was significantly $(P<0.05)$ increased during sodium butyrate infusion, and the clearance of urea to the lower digestive tract was significantly $(P<0.05)$ decreased during $\mathrm{NH}_{4} \mathrm{Cl}$ infusion.

6. The mechanism by which urea entry into the rumen is regulated by rumen metabolite levels is discussed.
\end{abstract}

The rate at which urea is recycled to and degraded in the digestive tract of ruminants has been shown to vary with the protein content of the diet (Cocimano \& Leng, 1967; Faichney \& White, 1977), the presence of readily fermentable carbohydrate in the ration (Cocimano \& Leng, 1967; Potthast et al. 1977; Engelhardt et al. 1978; Kennedy, 1980; Norton et al. 1982), the level of digestible organic matter intake (Kennedy \& Milligan, 1978; Kennedy, 1980), the age of the animal (Allen \& Miller, 1976), environmental temperature (Kennedy \& Milligan, 1978) and with time after feeding (Varady et al. 1969).

However, less is known about the specific factors regulating urea entry into the digestive tract of feeding ruminants, although the likely site of increased entry is through the rumen wall from blood (Kennedy \& Milligan, 1978; Norton et al. 1982). Studies with temporarily isolated rumen preparations have demonstrated that various end-products of fermentation

\footnotetext{
* Present address: Department of Agriculture, University of Queensland, St Lucia. Queensland 4067, Australia.
} 
affect the rate of urea entry into the rumen. Ammonia concentrations in rumen fluid have been inversely correlated with urea recycling to the rumen (Weston \& Hogan, 1967; Thornton, 1970; Harrop \& Phillipson, 1974; Kennedy, 1980) and bacterial urease activity in the rumen wall has been suggested as a regulatory factor in urea transport from blood to rumen fluid (Houpt, 1970; Cheng \& Wallace, 1979). Volatile fatty acids, particularly butyric acid, stimulate urea entry into the rumen (Dobson et al. 1971; Hinderer \& Engelhardt, 1976), and temporarily isolated bovine rumen preparations have a high permeability to urea when gassed with $\mathrm{CO}_{2}$ (Thorlacius et al. 1971; Hinderer \& Engelhardt, 1976). The synthetic gastric hormone, pentagastrin, has also been shown to stimulate urea entry into the rumen (Harrop \& Phillipson, 1971). Although both butyric acid and $\mathrm{CO}_{2}$ stimulate blood flow to the rumen epithelia (Sellers et al. 1964; Thorlacius, 1972), increased blood flow rate alone does not increase the rate of urea passage in the rumen (Dobson $e t$ al. 1971).

The experiments with urea recycling in feeding animals may be generally criticized for a lack of information on the effects of diet on fermentation patterns in the rumen associated with increased urea recycling rate, and the relevance of studies with temporarily isolated rumen preparations to the feeding animal are questionable. In a previous study, increased urea recycling to the rumen was associated with increased concentrations of butyric acid in rumen fluid and with high rates of $\mathrm{CO}_{2}$ production from fermentation, but it was not possible from these experiments to relate specific metabolite changes with altered rates of urea recycling (Norton et al. 1982).

The following experiment was therefore designed to study the effects of intraruminal infusions of sodium butyrate, sodium bicarbonate and ammonium chloride on urea metabolism in sheep offered a pelleted-grass diet. Infusion rates were selected to produce a change in metabolite concentration in rumen liquor within the normal physiological range, and urea recycling to the rumen and lower digestive tract was determined with an isotope dilution technique.

\section{MATERIALS AND METHODS}

\section{Animals, diet and management}

Three Scottish Blackface wethers ( 8 months old), fitted with rumen cannulas, were introduced to a diet of pelleted-grass cubes over a 3-week period and maintained on this diet for the duration of the experiment. The mean live weight of the sheep was $41.2 \mathrm{~kg}$ (range $39 \cdot 4-44 \cdot 3)$, and all gained weight $(80 \mathrm{~g} / \mathrm{d})$ during the experiment. All sheep were held in individual metabolism cages in a temperature-controlled room and were offered $1000 \mathrm{~g}$ grass cubes (as fed) daily from an hourly feeding machine. The average composition of the pelleted-grass diet was: $893 \mathrm{~g}$ dry matter (DM)/kg air-dry food, $25.7 \mathrm{~g}$ nitrogen and $916 \mathrm{~g}$ organic matter (OM) $/ \mathrm{kg}$ DM. The DM, OM and $\mathrm{N}$ content of the food varied slightly between the different infusion periods, and actual values for $\mathrm{N}$ and $\mathrm{OM}$ intakes may be calculated from the results given in Table 1 (see p. 268). Drinking water was available at all times, and with the exception of one sheep in the first experimental period, all food offered was consumed.

\section{Experimental procedure}

The experimental period of 8 weeks was divided into four 2-week periods, and during each period, all sheep were intraruminally infused $(0.45 \mathrm{l} / \mathrm{d})$ successively with one of the following solutions in the order shown: sodium chloride $(1.04 \mathrm{~mol} / \mathrm{l})$, sodium bicarbonate $(1.04 \mathrm{~mol} / \mathrm{l})$, ammonium chloride $\left(1.04 \mathrm{~mol} \mathrm{NH}_{4} \mathrm{Cl}\right.$ and $\left.1.04 \mathrm{~mol} \mathrm{NaCl} / \mathrm{l}\right)$ and sodium butyrate ( $1.04 \mathrm{~mol}$ butyric acid and $1.04 \mathrm{~mol}$ sodium (as $\mathrm{NaOH}$ and $\mathrm{NaCl}$ )/1). All solutions, 
except $\mathrm{NaHCO}_{3}$ (pH 8.2), were adjusted to $\mathrm{pH} 7$ for infusion. These infusion solutions provided a constant $\mathrm{Na}$ intake $(10.8 \mathrm{~g} / \mathrm{d})$ to all sheep during each infusion period.

In each 2 -week period, the first week was allowed for adaptation to infusion treatment and balance trials and isotope infusion experiments were conducted in the second week of this period. Urine was collected continuously by aspiration from a rubber belly tank into a bottle containing glacial acetic acid as preservative, and after subsampling, urine was stored frozen until analysed. Faeces were collected daily and also stored frozen. On the tenth day of each infusion period, each sheep was fitted with a jugular vein catheter and was continuously infused intravenously with a sterile saline solution $(9 \mathrm{~g} \mathrm{NaCl} / \mathrm{l})$ containing $\left[{ }^{14} \mathrm{C}\right]$ urea $(0.12 \mu \mathrm{Ci} / \mathrm{ml} ; 0.8 \mu \mathrm{mol} / \mathrm{ml} ; 0.3 \mathrm{ml} / \mathrm{min})$ for $24 \mathrm{~h}$. An intravenous infusion of a sterile saline solution containing $\mathrm{NaH}^{14} \mathrm{CO}_{2}(0.13 \mu \mathrm{Ci} / \mathrm{ml} ; 1.2 \mu \mathrm{mol} / \mathrm{ml} ; 0.3 \mathrm{ml} / \mathrm{min})$ immediately followed the $\left[{ }^{14} \mathrm{C}\right]$ urea infusion and was also maintained for $24 \mathrm{~h}$. At the end of the infusion, the jugular catheter was removed and an intraruminal infusion of $\mathrm{NaH}^{14} \mathrm{CO}_{3}$ in water $(0.13 \mu \mathrm{Ci} / \mathrm{ml} ; 1.2 \mu \mathrm{mol} / \mathrm{min})$ was maintained for a further $24 \mathrm{~h}$. In the final $8 \mathrm{~h}$ of this infusion, the jugular catheter was removed and an intraruminal infusion of $\mathrm{NaH}^{14} \mathrm{CO}_{3}$ rumen fluid sampled from an indwelling ruminal probe. After removal of an aliquot for bicarbonate determination, heparinized blood was centrifuged at $1500 \mathrm{~g}$ for $20 \mathrm{~min}$, and plasma stored at $-20^{\circ}$. Rumen fluid was immediately subsampled for bicarbonate determination $(0.5 \mathrm{ml})$, ammonia $(10 \mathrm{ml}$ diluted with $10 \mathrm{ml} 0.2 \mathrm{M}$-hydrochloric acid), volatile fatty acids (VFA) (4 ml added to $1 \mathrm{ml}$ metaphosphoric acid) and $\mathrm{pH}$ and osmolality were immediately determined on the remaining sample.

\section{Analytical methods}

Urea in blood and urine was determined by a modification of the Boehringer test (Fawcett \& Scott, 1960). Plasma was protein-precipitated before urea determination (Cocimano \& Leng, 1967). The concentration and specific radioactivity $(S R)$ of bicarbonate in blood and rumen liquor were determined by methods described by Norton et al. (1982). Ammonia in rumen fluid and total $\mathrm{N}$ in food, faeces and urine were determined by the Kjeldahl method, and the concentrations and proportions of VFA in rumen fluid were determined on a Pye 204 gas-liquid chromatograph (Cottyn \& Boucque, 1968). Osmolality of rumen fluid samples was measured in an Advanced Laboratory Osmometer (model 36: Advanced Instruments Inc., Massachussets) and $\mathrm{pH}$ determined on a digital $\mathrm{pH}$ meter.

\section{Calculations and statistical methods}

The irreversible loss of bicarbonate-C from blood and rumen fluid, and urea-C from blood, the relative contributions of primary (infused) pool to secondary pools and the transfer rates of $\mathrm{C}$ between blood urea, rumen fluid bicarbonate and blood bicarbonate were calculated by methods previously described (Norton et al. 1982). Analysis of variance was used to determine the significance of differences between sheep and between treatments, and least significant difference (LSD) calculated to distinguish treatment differences. In the first infusion period, one sheep refused food and a missing value was calculated (Steele \& Torrie, 1960). The subsequent analysis of variance was corrected for bias caused by the use of a missing plot value in the statistical analysis.

\section{RESULTS}

\section{The effect of intraruminal infusions on diet utilization}

Small differences in feed $\mathrm{N}$ and DM content between treatment periods resulted in small differences in $\mathrm{N}$ and oM intakes for sheep in the different infusion periods. Table 1 shows mean values, with their standard errors, for the effects of the different infusions on the 
Table 1. Mean values for the digestibility and utilization of dietary organic matter and nitrogen, and for water intake and urine excretion of sheep intraruminally infused $(0.47 \mathrm{~mol} / \mathrm{d})$ with sodium chloride, sodium bicarbonate, ammonium chloride and sodium butyrate

\begin{tabular}{|c|c|c|c|c|c|}
\hline Infusion treatment & $\mathrm{NaCl}$ & $\mathrm{NaHCO}_{3}$ & $\mathrm{NH}_{4} \mathrm{Cl}$ & $\begin{array}{l}\text { Sodium } \\
\text { butryate }\end{array}$ & $\begin{array}{l}\text { SE of } \\
\text { mean }\end{array}$ \\
\hline \multicolumn{6}{|l|}{ Organic matter } \\
\hline Apparent digestibility & 0.709 & 0.687 & 0.706 & 0.718 & $0 \cdot 008$ \\
\hline Apparently digested intake $(\mathrm{g} / \mathrm{d})$ & $576_{\mathrm{at},}+$ & 560 & $589_{\mathrm{bc}-}$ & 612 & $7^{*}$ \\
\hline \multicolumn{6}{|l|}{ Nitrogen } \\
\hline Apparent digestibility & $0.678_{\mathrm{a}}$ & $0.655_{i}$ & $0 \cdot 717 \mathrm{~b}$ & $0.647_{\mathrm{ac}}$ & $0.007^{*}$ \\
\hline Faecal excretion $(\mathrm{g} \mathrm{N} / \mathrm{d})$ & $7 \cdot 71$ & $7 \cdot 89$ & $8 \cdot 33$ & $7 \cdot 73$ & $0 \cdot 16$ \\
\hline Urinary excretion ( $\mathrm{g} \mathrm{N} / \mathrm{d}$ ) & $12 \cdot 44_{u}$ & $11 \cdot 36_{a}$ & $18 \cdot 14_{b}$ & $10 \cdot 84 a$ & $0.74^{*}$ \\
\hline $\mathrm{N}$ balance $(\mathrm{g} \mathrm{N} / \mathrm{d})$ & $3 \cdot 80^{a}$ & $3 \cdot 61$ & 2.99 & $3 \cdot 32^{d}$ & 0.84 \\
\hline Apparently digested $\mathrm{N}$ retained & 0.240 & 0.238 & $0 \cdot 142$ & 0.234 & 0.051 \\
\hline Water intake $(1 / \mathrm{d})$ & $2 \cdot 97$ & 3.03 & $3 \cdot 31$ & 2.90 & $0 \cdot 12$ \\
\hline Urine volume $(\mathrm{l} / \mathrm{d})$ & $1 \cdot 75_{a}$ & $1 \cdot 78_{a \mathfrak{a}}$ & $1.90_{d a}$ & $1.47 \mathrm{~b}$ & $0.05^{*}$ \\
\hline
\end{tabular}

* Significant difference between treatment means $(P<0.05)$.

$\uparrow$ Values within a line with different subscripts differ significantly $(P<0.05)$.

apparent digestibility of $\mathrm{OM}$ and $\mathrm{N}$, for $\mathrm{N}$ excretion in urine and faeces and for water intake and urine volume. Each treatment supplied the same daily infusion of sodium $(10.8 \mathrm{~g} / \mathrm{d})$, and treatment effects are described as differences from the $\mathrm{NaCl}$ treatment. Sodium butyrate infusion significantly $(P<0.05)$ increased apparently digested OM intake (ADOM) by $36 \mathrm{~g} / \mathrm{d}$ without affecting either $\mathrm{N}$ or $\mathrm{OM}$ digestibility, but significantly $(P<0.05)$ decreased daily urine volume.

$\mathrm{NH}_{4} \mathrm{Cl}$ infusion increased total $\mathrm{N}$ intake by $6.2 \mathrm{~g} / \mathrm{d}$, and the significant $(P<0.05)$ increase in urinary $\mathrm{N}$ excretion by these sheep accounted for $93 \%$ of the $\mathrm{N}$ infused. The additional $\mathrm{N}$ load was excreted in urine by an increased daily volume of urine $(9 \%)$ and an increased concentration of $\mathrm{N}$ in urine $(36 \%)$. There was no significant effect of infusion treatment on $\mathrm{N}$ balance, and with the exception of sheep infused with $\mathrm{NH}_{4} \mathrm{Cl}$, sheep utilized apparently digested $\mathrm{N}$ with a similar efficiency for $\mathrm{N}$ retention in tissues.

\section{The effect of intraruminal infusion on rumen fluid constituents}

Table 2 shows mean values, with their standard errors, for the concentrations and proportions of VFA in rumen fluid, for bicarbonate and ammonia concentrations and for the $\mathrm{pH}$ and osmolality of rumen fluid from sheep infused with the different solutions. $\mathrm{NaHCO}_{3}$ significantly $(P<0.05)$ increased bicarbonate concentrations and the $\mathrm{pH}$ of ruminal liquor, but had no significant effect on the concentrations and proportions of VFA, ammonia concentration or the osmolality of rumen fluid. $\mathrm{NH}_{4} \mathrm{Cl}$ infusion significantly $(P<0.05)$ increased rumen ammonia concentration, but neither $\mathrm{pH}$ nor osmolality were significantly affected by this infusion. Sodium butyrate infusion significantly $(P<0.05)$ increased the concentration and proportion of butyric acid and decreased the proportion of acetic acid in rumen fluid, and increased $\mathrm{pH}$. There was no significant effect of sodium butyrate infusion on either ammonia concentrations or osmolality of rumen fluid.

\section{Bicarbonate metabolism in ruminal liquor and blood}

Table 3 shows mean values, with their standard errors, for the concentrations and irreversible loss of bicarbonate- $C$ from blood and rumen fluid of sheep infused with the different solution. Values for the percentage contribution of primary (infused) pool to secondary pools during each isotope infusion are also presented. 
Table 2. Mean values for the concentrations of volatile fatty acids (total and individual), bicarbonate and ammonia in rumen fluid, and for $\mathrm{pH}$ and osmolality of rumen fluid from sheep given a pelleted-grass diet and intraruminally infused $(0.47 \mathrm{~mol} / \mathrm{d})$ with sodium chloride, sodium bicarbonate, ammonium chloride and sodium butyrate

\begin{tabular}{|c|c|c|c|c|c|}
\hline Infusion treatment & $\mathrm{NaCl}$ & $\mathrm{NaHCO}_{3}$ & $\mathrm{NH}_{4} \mathrm{Cl}$ & $\begin{array}{l}\text { Sodium } \\
\text { butyrate }\end{array}$ & $\begin{array}{l}\mathrm{SE} \text { of } \\
\text { mean }\end{array}$ \\
\hline Total VFA (mmol/l) & 91 & 108 & 111 & 117 & 8 \\
\hline \multicolumn{6}{|c|}{ Individual VFA (mmol $/ \mathrm{mol}$ total VFA) } \\
\hline Acetic acid & $618_{\mathrm{a}} \dagger$ & $600_{\mathrm{a}}$ & $625_{\mathrm{a}}$ & $545_{b}$ & $14^{*}$ \\
\hline Propionic acid & $239^{11}$ & $244^{\circ}$ & $246^{a}$ & $252^{\circ}$ & 14 \\
\hline Butyric acid & $113_{\mathbf{a}}$ & $112_{\mathrm{a}}$ & $95_{\mathrm{a}}$ & $170_{b}$ & $6^{* *}$ \\
\hline Higher acids & 30 & $44^{a}$ & $34^{a}$ & 33 & 7 \\
\hline Ammonia (mg $N / 1)$ & $7 \mathbf{1}_{\mathrm{a}}$ & $65_{\mathrm{a}}$ & $171_{\mathrm{h}}$ & $53_{\mathrm{a}}$ & $12^{* *}$ \\
\hline $\mathrm{pH}$ & $6 \cdot 22_{a}$ & $6 \cdot 63_{b}$ & $6.17_{\mathrm{a}}$ & $6 \cdot 58_{b}$ & $0 \cdot 09^{*}$ \\
\hline Osmolality (mosmol/kg) & 307 & 308 & 307 & 319 & 11 \\
\hline
\end{tabular}

* $P<0.05, \quad$ ** $P<0.01$.

$\dagger$ Values within a line with different subscripts differ significantly $(P<0.05)$.

Table 3. Mean values for the concentrations and irreversible losses of bicarbonate from rumen fluid and blood, and for the relative contributions of bicarbonate and urea-C to the different pools of sheep given a pelleted-grass diet and intraruminally infused $(0.47 \mathrm{~mol} / \mathrm{d})$ separately with sodium chloride, sodium bicarbonate, ammonium chloride and sodium butyrate

\begin{tabular}{|c|c|c|c|c|c|}
\hline Infusion treatment & $\mathrm{NaCl}$ & $\mathrm{NaHCO}_{3}$ & $\mathrm{NH}_{4} \mathrm{Cl}$ & $\begin{array}{l}\text { Sodium } \\
\text { butyrate }\end{array}$ & $\begin{array}{l}S E \text { of } \\
\text { mean }\end{array}$ \\
\hline \multicolumn{6}{|l|}{ Rumen fluid bicarbonate } \\
\hline Concentration (g C/l) & $0 \cdot 386_{\mathrm{a}} \dagger$ & $0.543_{b}$ & $0 \cdot 326_{\mathrm{a}}$ & $0.447_{\mathrm{ab}}$ & $0.032^{*}$ \\
\hline Irreversible loss $(\mathrm{g} \mathrm{C} / \mathrm{d})$ & $132 \cdot 0$ & $118 \cdot 7$ & $115 \cdot 9$ & $113 \cdot 3$ & $7 \cdot 8$ \\
\hline \multicolumn{6}{|c|}{ Percentage of rumen bicarbonate from } \\
\hline Blood bicarbonate & $33 \cdot 6$ & $33 \cdot 9$ & $37 \cdot 7$ & $47 \cdot 3$ & $4 \cdot 8$ \\
\hline Blood urea & $1 \cdot 3_{\mathrm{a}}$ & $1 \cdot 1_{\mathrm{a}}$ & $1 \cdot 3_{\mathrm{a}}$ & $2 \cdot 5_{b}$ & $0 \cdot 2^{*}$ \\
\hline \multicolumn{6}{|l|}{ Blood bicarbonate } \\
\hline Concentration $(\mathrm{g} \mathrm{C} / \mathrm{l})$ & $0 \cdot 268_{\mathrm{ac}}$ & $0.315_{\mathrm{b}}$ & $0 \cdot 241_{\mathbf{a}}$ & $0 \cdot 286_{c}$ & $0.007^{* *}$ \\
\hline Irreversible loss $(\mathrm{g} \mathrm{C} / \mathrm{d})$ & $261 \cdot 8$ & $274 \cdot 8$ & $247 \cdot 1$ & $270 \cdot 1$ & $19 \cdot 2$ \\
\hline \multicolumn{6}{|c|}{ Percentage of blood bicarbonate from } \\
\hline Rumen bicarbonate & $49 \cdot 3$ & $34 \cdot 3$ & $37 \cdot 8$ & $35 \cdot 1$ & 60 \\
\hline Blood urea & $1 \cdot 0$ & 0.8 & $1 \cdot 1$ & $2 \cdot 2$ & 0.4 \\
\hline
\end{tabular}

* $P<0.05,{ }^{* * *} P<0.01$.

$\dagger$ Values within a line with different subscripts differ significantly $(P<0.05)$.

Although there was a significant $(P<0.05)$ effect of treatment on the concentrations of bicarbonate- $C$ in rumen fluid, there was no significant effect of infusion treatment on the irreversible loss of bicarbonate-C from rumen fluid. There was a highly significant correlation $(r 0.90, P<0.01)$ between bicarbonate concentrations in rumen fluid and $\mathrm{pH}$. The infusion of $\mathrm{NaHCO}_{3}$ significantly $(P<0.05)$ increased bicarbonate concentrations in blood. The irreversible loss of bicarbonate- $C$ from blood was significantly correlated $(r 0.83)$ with blood bicarbonate concentrations. A significantly $(P<0.05)$ greater proportion of rumen bicarbonate- $\mathrm{C}$ was derived from blood urea- $\mathrm{C}$ when sodium butyrate was infused, and for this infusion there was a trend for a greater proportion of rumen bicarbonate to be derived from blood bicarbonate than that found for the other infusion treatments. 
Table 4. Mean values for plasma urea concentration, irreversible loss of urea from blood, urinary urea excretion and degradation of urea in the rumen and lower digestive tract of sheep given a pelleted-grass diet and intraruminally infused $(0.47 \mathrm{~mol} / \mathrm{d})$ separately with sodium chloride, sodium bicarbonate, ammonium chloride and sodium butyrate

\begin{tabular}{|c|c|c|c|c|c|}
\hline Infusion treatment & $\mathrm{NaCl}$ & $\mathrm{NaHCO}_{3}$ & $\mathrm{NH}_{4} \mathrm{Cl}$ & $\begin{array}{l}\text { Sodium } \\
\text { butyrate }\end{array}$ & $\begin{array}{l}\text { SE of } \\
\text { mean }\end{array}$ \\
\hline \multicolumn{6}{|l|}{ Blood urea } \\
\hline Concentration (mg N/l) & $111_{a} \dagger$ & $108_{\mathrm{a}}$ & $162_{b}$ & $99 \mathrm{a}$ & $6^{* *}$ \\
\hline Irreversible loss ( $\mathrm{g} \mathrm{N} / \mathrm{d})$ & $19 \cdot 98_{\mathrm{a}}$ & $20 \cdot 83_{\mathrm{a}}$ & $24 \cdot 92_{b}$ & $20 \cdot 25$ & $0.62^{* *}$ \\
\hline Urinary urea $(\mathrm{g} \mathrm{N} / \mathrm{d})$ & $8 \cdot 98_{\mathrm{a}}$ & $7 \cdot 75_{\mathrm{a}}$ & $15 \cdot 91_{b}$ & $7 \cdot 31_{\mathrm{a}}^{\mathrm{a}}$ & $0.59 * *$ \\
\hline \multicolumn{6}{|l|}{ Total urea degradation $\neq$} \\
\hline $\mathrm{gN} / \mathrm{d}$ & $11 \cdot 25$ & $13 \cdot 31$ & $9 \cdot 33$ & $13 \cdot 44$ & $1 \cdot 38$ \\
\hline As a percentage of urea synthesized & $55 \cdot 6_{\mathrm{a}}$ & $63 \cdot 2_{\mathrm{a}}$ & $37 \cdot 0_{\mathrm{b}}$ & $64 \cdot 8_{\mathrm{a}}$ & $3 \cdot 2^{*}$ \\
\hline \multicolumn{6}{|l|}{ Degradation of urea in the rumen } \\
\hline $\mathrm{g} \mathrm{N} / \mathrm{d}$ & $1 \cdot 51_{a}$ & $1 \cdot 39 \mathrm{a}$ & $1 \cdot 79_{\mathrm{a}}$ & $3 \cdot 21_{b}$ & $0 \cdot 36^{*}$ \\
\hline Clearance $(1 / d) \S$ & $13 \cdot 6_{a}^{a}$ & $12 \cdot 9_{\mathrm{a}}{ }^{\mathrm{a}}$ & $11 \cdot 0_{\mathrm{a}}^{\mathrm{a}}$ & $32 \cdot 4_{b}$ & $3 \cdot 4^{*}$ \\
\hline As a percentage of total urea degradation & $13 \cdot 4^{a}$ & $10 \cdot 4$ & $19 \cdot 2$ & $23 \cdot 9$ & $3 \cdot 9$ \\
\hline \multicolumn{6}{|l|}{ Degradation of urea in lower digestive tract } \\
\hline $\mathrm{g} \mathrm{N} / \mathrm{d}$ & $9 \cdot 74$ & $11 \cdot 92$ & $7 \cdot 54$ & $10 \cdot 23$ & 1.48 \\
\hline Clearance $(1 / d)$ & $87 \cdot 7_{\mathrm{ab}}$ & $110 \cdot 4_{a}$ & $46 \cdot 5_{b}$ & $103 \cdot 3_{\mathrm{a}}$ & $12 \cdot 1 *$ \\
\hline As a percentage of total urea degradation & $86 \cdot 6$ & $89 \cdot 6^{\circ}$ & $80 \cdot 8$ & $76 \cdot 1$ & 3.9 \\
\hline
\end{tabular}

\section{The effect of intraruminal infusions on urea metabolism}

Mean values, with their standard errors, for plasma urea concentration, irreversible loss of urea from blood, excretion of urea in urine and for urea degradation in the rumen and lower digestive tract are shown in Table 4 . Infusion with $\mathrm{NH}_{4} \mathrm{Cl}$ significantly $(P<0.05)$ increased plasma urea concentration and urinary urea excretion. Sodium butyrate infusion significantly $(P<0.05)$ increased both the amount and proportion of total urea synthesis that was degraded in the rumen. The clearance of urea from blood into the rumen was also significantly $(P<0.05)$ increased during sodium butyrate infusion. Urea degradation in the lower digestive tract was not affected significantly by treatment when expressed as either amount degraded $(\mathrm{g} / \mathrm{d})$ or as the proportion of total urea degradation occurring in the whole digestive tract although the clearance of urea into the lower digestive tract was decreased when $\mathrm{NH}_{4} \mathrm{Cl}$ was infused.

Models of carbon metabolism in sheep during infusion with the different treatments The values shown in Tables 3 and 4 were used to calculate the rates of $C$ transfer between blood urea, blood bicarbonate and rumen fluid bicarbonate pools for sheep during each infusion treatment. Table 5 gives mean values, with standard errors, for the rates of $\mathrm{C}$ movement between the above-mentioned pools and for the rates of production and excretion of $\mathrm{C}$ from each pool. As described previously, sodium butyrate infusion significantly $(P<0.05)$ increased urea recycling to the rumen, and $\mathrm{NH}_{4} \mathrm{Cl}$ infusion significantly $(P<0.05)$ increased the rate of urea synthesis and urinary urea excretion. However, there were no significant effects of infusion treatments on the quantitive exchange of bicarbonate- $\mathrm{C}$ between the ruminal and blood pools, or on the amounts of bicarbonate- $\mathrm{C}$ arising from tissue metabolism or rumen fermentation. 
Table 5. Mean values for the transfer rates $(g C / d)$ between blood urea, rumen fluid bicarbonate and blood bicarbonate in sheep given a pelleted-grass diet and intraruminally infused $(0.47 \mathrm{~mol} / \mathrm{d})$ separately with sodium chloride, sodium bicarbonate, ammonium chloride and sodium butyrate

\begin{tabular}{|c|c|c|c|c|c|}
\hline Infusion treatment & $\mathrm{NaCl}$ & $\mathrm{NaHCO}_{3}$ & $\mathrm{NH}_{4} \mathrm{Cl}$ & $\begin{array}{l}\text { Sodium } \\
\text { butyrate }\end{array}$ & $\begin{array}{l}\text { SE of } \\
\text { mean }\end{array}$ \\
\hline \multicolumn{6}{|l|}{ Blood urea (g C/d) } \\
\hline From blood bicarbonate & $8 \cdot 67$ & $9 \cdot 02$ & $10 \cdot 82$ & 8.90 & 0.65 \\
\hline To degradation in rumen & $0.65_{a} \dagger$ & $0.60_{a}$ & $0.77_{\mathrm{a}}$ & $1 \cdot 37_{b}$ & $0.15^{*}$ \\
\hline To post-ruminal tract & $4 \cdot 17^{4}$ & $5 \cdot 10$ & $3.23^{\circ}$ & $4 \cdot 40^{\circ}$ & 0.64 \\
\hline To urine & $3.85_{\mathrm{a}}$ & $3 \cdot 32_{\mathrm{a}}$ & $6 \cdot 82_{b}$ & $3 \cdot 13_{\mathrm{a}}$ & $0 \cdot 24^{* *}$ \\
\hline \multicolumn{6}{|l|}{ Blood bicarbonate (g C/d) } \\
\hline From tissue metabolism & $207 \cdot 8$ & $203 \cdot 2$ & $179 \cdot 5$ & $210 \cdot 4$ & $11 \cdot 2$ \\
\hline From rumen bicarbonate & $105 \cdot 1$ & $107 \cdot 4$ & $109 \cdot 4$ & $113 \cdot 8$ & $15 \cdot 3$ \\
\hline To expiration and excretion & $228 \cdot 3$ & $259 \cdot 0$ & $228 \cdot 9$ & 257.8 & $10 \cdot 5$ \\
\hline To rumen bicarbonate & $78 \cdot 8$ & $45 \cdot 2$ & $51 \cdot 7$ & $63 \cdot 4$ & $11 \cdot 6$ \\
\hline \multicolumn{6}{|l|}{ Rumen bicarbonate $(\mathrm{g} \mathrm{C} / \mathrm{d})$} \\
\hline From fermentation & $79 \cdot 2$ & $89 \cdot 4$ & $83 \cdot 0$ & $71 \cdot 5$ & $9 \cdot 7$ \\
\hline To eructation & $53 \cdot 6$ & $27 \cdot 8$ & $26 \cdot 2$ & $22 \cdot 4$ & 8.9 \\
\hline
\end{tabular}

* $P<0.05, \quad * * P<0.01$.

$\uparrow$ Values within a line with different subscripts differ significantly $(P<0.05)$.

\section{DISCUSSION}

In these experiments, sodium butyrate infusion stimulated urea recycling to the rumen, and contrary to expectation neither ammonia nor bicarbonate concentration in rumen fluid affected the rate of urea recycling. However, there was no significant effect of any infusion treatment on $\mathrm{N}$ balance or on efficiency of $\mathrm{N}$ utilization. When $\mathrm{NH}_{4} \mathrm{Cl}$ was infused, rumen ammonia concentrations increased threefold, and the equivalent of the additional $\mathrm{N}$ infused $(6.2 \mathrm{~g} / \mathrm{d})$ was almost entirely excreted in urine, indicating that rumen ammonia concentrations ( $50-70 \mathrm{mg} \mathrm{N} / \mathrm{l})$ were probably not limiting fermentation rate and microbial growth in the rumen (Satter \& Slyter, 1974). The additional $N$ recycled to the rumen during sodium butyrate infusion was also apparently in excess of microbial requirements since tissue $\mathrm{N}$ balance remained the same as that in the control infusion period.

The mechanisms regulating urea entry into the rumen have been recently reviewed (Engelhardt et al. 1978; Kennedy \& Milligan, 1980), and there is general agreement that the nature of rumen fluid metabolites significantly affects the extent to which blood urea is recycled to the rumen. However, the specific site of action of these metabolites and dietary conditions leading to increased urea recycling are still not clear. Thorlacius et al. (1971) demonstrated that gaseous $\mathrm{CO}_{2}$ increased urea entry through the wall of temporarily isolated rumen of cattle. High rates of urea entry were localized to the area of $\mathrm{CO}_{2}$ application and increased as both plasma urea concentration and the partial pressure of $\mathrm{CO}_{2}$ increased. Both acetamide and thiourea entry into the rumen were also stimulated by gaseous $\mathrm{CO}_{2}$ indicating that urease $[E C$ 3.5.1.5] activity was not involved in the stimulation of transport rate. In the absence of gaseous $\mathrm{CO}_{2}$, urea entry into the rumen was independent of plasma urea concentration, and the previously mentioned obscrvations suggest that gaseous $\mathrm{CO}_{2}$ affects the permeability of either the capillary wall or the rumen mucosa to urea. Sellers et al. (1964) observed that both $\mathrm{CO}_{2}$ and VFA stimulated blood flow to the rumen arteries, but in later studies by the same group, urea entry into the rumen was found not to alter during a fourfold increase in blood flow rate (Dobson et al. 1971).

Rumen gas varies from 10 to $80 \% \mathrm{CO}_{2}$, depending on the feeding regimen and time after 
Table 6. The effect of $\mathrm{pH}$ on the carbonic acid and bicarbonate concentrations $(\mathrm{mmol} / \mathrm{l})$ in rumen fluid of sheep intraruminally infused $(0.44 \mathrm{~mol} / \mathrm{d})$ with sodium chloride, sodium bicarbonate, ammonium chloride and sodium butyrate

\begin{tabular}{lcccc}
\hline \hline Infusion treatment & $\mathrm{NaCl}$ & $\mathrm{NaHCO}_{3}$ & $\mathrm{NH}_{4} \mathrm{Cl}$ & $\begin{array}{c}\text { Sodium } \\
\text { butyrate }\end{array}$ \\
\hline$\left[\mathrm{H}_{2} \mathrm{CO}_{3}+\mathrm{HCO}_{3}{ }^{-}\right]$ & $32 \cdot 2$ & $45 \cdot 3$ & $27 \cdot 2$ & $37 \cdot 3$ \\
$\mathrm{pH}$ & $6 \cdot 22$ & $6 \cdot 63$ & $6 \cdot 17$ & $6 \cdot 58$ \\
$\mathrm{Proportion}$ as $\mathrm{H}_{2} \mathrm{CO}_{3}$ & $0 \cdot 63$ & $0 \cdot 40$ & 0.66 & $0 \cdot 43$ \\
{$\left[\mathrm{HCO}_{3}\right]^{*}$} & $11 \cdot 8$ & $27 \cdot 1$ & $9 \cdot 3$ & $21 \cdot 3$ \\
{$\left[\mathrm{H}_{2} \mathrm{CO}_{3}\right]^{*}$} & $20 \cdot 4$ & $18 \cdot 2$ & 17.9 & $16 \cdot 0$ \\
\hline
\end{tabular}

* Calculated from the Henderson-Hasselbach equation: $\mathrm{p} K_{\alpha}=\mathrm{pH}+\log _{10}\left(\left[\mathrm{H}_{2} \mathrm{CO}_{3}\right] /\left[\mathrm{HCO}_{3}^{-}\right]\right)$, where $K_{a}=3.5 \times 10^{7}$.

feeding (Washburn \& Brody, 1937; Barry et al. 1977). In our experiments, all sheep were fed hourly which would result in constant and probably low partial pressures of $\mathrm{CO}_{2}$ in rumen gas, and these conditions would not be conducive to $\mathrm{CO}_{2}$-stimulated urea recycling to the rumen. Furthermore, as shown in Table 6, although $\mathrm{NaHCO}_{3}$ infusion had a significant effect on bicarbonate ion concentrations in rumen fluid, there was little effect of any treatment on carbonic acid concentrations in rumen fluid. If carbonic acid was in equilibrium with gaseous $\mathrm{CO}_{2}$, then the infusion of $\mathrm{NaHCO}_{3}$ was not effective in increasing the partial pressure of $\mathrm{CO}_{2}$ in rumen gas, and it is perhaps not surprising that urea recycling was not increased during this infusion period. Neither blood flow nor urea entry into the rumen are responsive to bicarbonate ion concentrations as shown in the studies of Dobson et al. (1971) where phosphate buffers were substituted with bicarbonate buffer with little effect on the above measurements. Under practical feeding conditions, $\mathrm{CO}_{2}$-induced urea recycling would occur shortly after feeding and continue until low $\mathrm{CO}_{2}$ tensions in rumen gas prevailed. Diets containing readily fermentable carbohydrate and fed once daily would provide the greatest potential for increased urea recycling. Varady et al. (1969) observed a change in the rate of urea recycling to the rumen of sheep with time after feeding, and low rates of recycling are usually found in starved ruminants (Engelhardt et al. 1978). Both studies support the hypothesis that the permeability of the rumen wall to urea is either directly or indirectly controlled by the partial pressure of $\mathrm{CO}_{2}$ in rumen gas which is in turn related to the diet and physiological state of the animal.

Many workers have reported a correlation between blood urea concentrations, rumen ammonia concentrations and urea entry into the rumen (Weston \& Hogan, 1967; Vercoe, 1969; Thornton, 1970; McIntyre, 1971; Kennedy \& Milligan, 1978; Norton et al. 1978; Kennedy, 1980), and these results have been interpreted by some as evidence that rumen ammonia concentrations regulate the rate of urea entry into the rumen (Varady et al. 1967; Harrop \& Phillipson, 1974; Kennedy \& Milligan, 1978; Cheng \& Wallace, 1979; Wallace et al. 1979; Kennedy, 1980). But low rumen ammonia concentrations are not always associated with high rates of urea recycling to the rumen (Norton et al. 1978; Macrae $e t$ al. 1979; Kennedy, 1980), nor do high rumen ammonia concentrations necessarily inhibit urea recycling (Norton et al. 1982; present study).

Urea enters rumen fluid from blood by salivary secretions and by passive diffusion through a selectively permeable membrane in the rumen wall. Although urea diffuses through this membrane at a slower rate than water (Dobson et al. 1971), in the absence of microbial urease activity, urea concentration in rumen fluid will equilibrate with that in blood (Cheng \& Wallace, 1979). Houpt (1970) suggested that the permeability of the 
cornified (keratinized) epithelium limited urea diffusion into rumen fluid, and that bacterial urease imbedded in the cornified layer facilitated urea entry by hydrolysis of urea to the more freely diffusable ammonia. However, this theory assumes, firstly that total urease activity is limiting the rate of urea hydrolysis, secondly that liberated ammonia would exist as ammonia and not ammonium ions and would diffuse against a concentration gradient into rumen fluid rather than down the concentration gradient back to blood, and thirdly that whilst microbial urease can penetrate the epithelial layer, the much smaller urea molecule cannot diffuse from this layer.

Cheng \& Wallace (1979) found a significant decrease in urease activity in rumen fluid of sheep when ammonia concentrations were increased and proposed that a similar adaptive response of urease activity in the epithelial layer may regulate the amount of urea entering the rumen from blood.

Calculations from the data of Cheng \& Wallace (1979) indicate that for sheep with a rumen volume of $5 \mathrm{l}$, and with the lowest urease activity found $(0.49 \mu \mathrm{mol}$ ammonia released $/ \mathrm{ml}$ rumen fluid per min at $37^{\circ}$ ), there was still sufficient activity to hydrolyse $49 \mathrm{~g}$ urea-N daily, an amount far in excess of that likely to be transferred across the rumen wall (Hecker \& Nolan, 1971). Tillman \& Sidhu (1969) have also reported that urease activity in rumen fluid is in excess of the substrate available for hydrolysis. Since Wallace et al. (1979) found that urease activity associated with the rumen epithelium was significantly higher than that in rumen fluid, it is difficult to envisage urease activity per se under these conditions as a regulator of urea transport across the rumen wall.

Nolan \& Stachiw (1979) have reported that the appearance of ${ }^{14} \mathrm{CO}_{2}$ and ${ }^{15} \mathrm{NH}_{4}^{+}$in rumen fluid was in the same proportions as ${ }^{14} \mathrm{C}$ - and ${ }^{15} \mathrm{~N}$-labelled urea in blood, which indicates that all urea degraded in passage across the rumen wall enters ruminal fluid and that there is no substantial evidence supporting a preferential ammonia reabsorption into blood after subepithelial degradation of urea.

Houpt \& Houpt (1968) bave made the interesting observation that disruption of the keratinized epithelial layer with $\mathrm{NaOH}$ without obvious damage to the underlying cells resulted in a fifty-fold increase in the rate of urea entry into the rumen. Under normal conditions, the rate of disintegration of this cornified layer will depend on a number of factors such as the rate of epithelial cell proliferation, its rate of keratinization and cell shedding, and on the extent of physical abrasion and on enzymic destruction of this layer by the microbial population inhabiting the wall. If the permeability of the rumen wall to urea is related to the thickness of the keratinized cell layer as the above evidence suggests, then permeability of the wall to urea may be altered by the effects of rumen metabolites on either microbial degradative activity in the rumen wall and/or by a direct effect on epithelial cell metabolism. For example, high butyric acid concentrations may stimulate microbial activity in the keratinized layer, increasing the rate of disruption of this cell layer resulting in higher rates of urea entry into rumen fluid. Alternatively, since butyric acid is extensively metabolized in the rumen epithelium (Weigand $e t$ al. 1972) the effects of high butyric acid concentrations in rumen liquor on urea recycling may be related to an increased rate of cell division and shedding. Similarly, the effects of $\mathrm{CO}_{2}$ on urea recycling may be related to microbial activity, since the effect of $\mathrm{CO}_{2}$ perfusion on urea entry is localized to the area of application, and is not immediate (Thorlacius et al. 1971).

The evidence presented previously suggests that the rate of urea entry into rumen fluid is related to plasma urea concentration and the permeability of the rumen wall to urea. Since neither blood flow rate nor urease activity per se appear to exercise control over urea entry, future studies of factors regulating urea passage through the rumen wall should concentrate on the effects of rumen metabolites $\left(\mathrm{CO}_{2}\right.$, VFA and $\left.\mathrm{NH}_{3}\right)$ on both microbial and epithelial cell activity as they relate to the thickness or integrity of the keratinized cell layer. Although 
the experiments reported in this paper have established that urea recycling through the rumen wall is inducible by dietary manipulation, and correlated with the concentrations of various rumen metabolites, the specific mechanism by which urea entry is increased still remains speculative.

The authors would like to thank Mr G. F. Brown, MRCVS, for the surgical preparation of the sheep, Mr D. Smith and Miss L. Hedgecock for their care of experimental animals and Mrs M. Atherton for willing assistance with sample collection and analysis.

\section{REFERENCES}

Allen, S. A. \& Miller, E. L. (1976). Br. J. Nutr. 36, 353.

Barry, T. N., Thompson, A. \& Armstrong, D. G. (1977). J. agric. Sci., Camb. 89, 183.

Cheng, K. J. \& Wallace, R. J. (1979). Br. J. Nutr. 42, 553.

Cocimano, M. R. \& Leng, R. A. (1967). Br. J. Nutr. 21, 353.

Cottyn, B. G. \& Boucque, C. V. (1968). J. agric. Fd Chem. 16, 105.

Dobson, A. J., Sellers, A. F. \& Thorlacius, S. O. (1971). Am. J. Physiol. 220, 1337.

Engelhardt, W. V., Hinderer, S. \& Wipper, E. (1978). In Ruminant Digestion and Feed Evaluation [D. F. Osbourn, D. G. Beever and D. J. Thomson, editors]. London: Agricultural Research Council.

Faichney, G. J. \& White, G. A. (1977). Aust. J. agric. Res. 28, 1069.

Fawcett, J. K. \& Scott, J. E. (1960). J. Clin. Path. 13, 156.

Harrop, C. T. F. \& Phillipson, A. T. (1971). Proc. Nutr. Soc. 30, 3 A.

Harrop, C. T. F. \& Phillipson, A. T. (1974). J. agric. Sci., Camb. 82, 339.

Hecker, J. F. \& Nolan, J. V. (1971). Aust. J. biol. Sci. 24, 403.

Hinderer, S. \& Engelhardt, W. V. (1976). In Tracer Studies on Non-protein Nitrogen for Ruminants, IIIrd Int. Conf., p. 59. Vienna: Atomic Energy Agency.

Houpt, T. R. (1970). In Physiology of Digestion and Metabolism in the Ruminant [A. T. Phillipson, editor]. Newcastle upon Tyne: Oriel Press.

Houpt, T. R. \& Houpt, K. A. (1968). Am. J. Physiol. 214, 1296.

Kennedy, P. M. (1980). Br, J. Nutr. 43, 125.

Kennedy, P. M. \& Milligan, L. P. (1978). Br. J. Nutr. 40, 149.

Kennedy, P. M. \& Milligan, L. P. (1980). Can. J. Anim. Sci. 60, 205.

McIntyre, K. H. C. (1971). Aust. J. agric. Res. 22, 429.

Macrae, J. C., Milne, J. A., Wilson, S. \& Spence, A. M. (1979). Br. J. Nutr. 42, 525.

Nolan, J. V. \& Stachiw, S. (1979). Br. J. Nutr. 42, 63.

Norton, B. W., Mackintosh, J. B. \& Amstrong, D. G. (1982). Br. J. Nutr. 48, 249.

Norton, B. W., Murray, R. M., Entwistle, K. W., Nolan, J. A., Ball, F. M. \& Leng, R. A. (1978). Aust. J. agric. Res. 29, 595.

Potthast, V., Prigge, H. \& Pfeffer, E. (1977). Z. Tierphysiol Tierenahr. Futter Mittelkd 38, 338.

Satter, L. D. \& Slyter, L. L. (1974). Br. J. Nutr. 32, 199.

Sellers, A. F., Stevens, C. E., Dobson, A. J. \& McLeod, F. D. (1964). Am. J. Physiol. 207, 371.

Steele, R. G. D. \& Torrie, J. H. (1960). Principles and Procedures of Statistics. London: McGraw-Hill.

Thorlacius, S. O. (1972). Am. J. vet. Res. 33, 427.

Thorlacius, S. O., Dobson, A. J. \& Sellers, A. F. (1971). Am. J. Physiol. 220. 162.

Thornton, R. F. (1970), Aust. J. agric. Res. 21, 337.

Tillman, A. D. \& Sidhu, K. A. (1969). J. Anim. Sci. 21, 337.

Varady, J., Boda, K., Havassy, I. \& Bajo, M. (1969). Physiol. Bohemoslov. 18, 23.

Varady, J., Boda, K., Havassy, I., Bajo, M. \& Tomas, J. (1967). Physiol. Bohemoslov. 16, 571.

Vercoe, J. E. (1969). Aust. J. agric. Res. $20,191$.

Wallace, R. J., Cheng, K. J., Dinsdale, D. \& Ørskov, E. R. (1979). Nature, Lond. $279,424$.

Washburn, L. E. \& Brody, S. (1937). Univ. Missouri, Agric. Res, Stat. Bull. 263.

Weigand, E., Young, J. W. \& McGilliard, A. D. (1972). J. Dairy Sci. 55, 589.

Weston, R. H. \& Hogan, J. P. (1967). Aust. J. biol. Sci. 20, 967. 